\section{OPEN ACCESS}

\title{
The effect of hopelessness on violence tendency: Turkish football fans Turkish football fans
}

\author{
Authors' contribution: \\ A) conception and design \\ of the study \\ B) acquisition of data \\ C) analysis and interpretation \\ of data \\ D) manuscript preparation \\ E) obtaining funding
}

\author{
Ilimdar Yalcin ${ }^{1 \mathrm{~A}-\mathrm{E}}$ (D), Nurullah Emir Ekinci²A,B (D), \\ Cihan Ayhan ${ }^{2 \mathrm{C}, \mathrm{E}}$ \\ ${ }^{1}$ Bingol University, Turkey \\ ${ }^{2}$ Yalova University, Turkey \\ ${ }^{3}$ Sakarya University of Applied Sciences, Turkey
}

*Correspondence: Ilimdar Yalcin, Bingol University, School of Physical Education and Sports, Bingol, Turkey; e-mail: ilimdaryalcin@gmail.com
Received: 16.05 .2020

Accepted: 20.04.2021

\begin{abstract}
This study aimed to analyze the relationship between the hopelessness and violence tendency of football fans and to investigate the differences between these variables and various demographic variables. The research group was formed by 398 male volunteer football fans who watched the Elazigspor (Sports Toto $1^{\text {st }}$ League) matches in the 2018-2019 season in Turkey. In addition to demographic variables in the study, the Violent Trend Scale and Beck Hopelessness Scale were used. The SPSS program was used to analyze the data. Independent sample t-test, one-way ANOVA, pearson correlation, and linear regression analysis were used in the analysis of the data. In the findings of the research, it was determined that there was a moderate positive relationship between the variable of hopelessness and the tendency toward violence. It was determined that there was a statistically significant difference in the tendency toward violence according to the variables of fans going to away games, the duration of watching matches at the stadium, and with whom fans watched the matches. As a result, as the level of fans' hopelessness increased, it was observed that there was an increase in violent tendencies. In addition, those who went to watch away matches, those who watched matches at the stadium for a long period of time, and those who went to watch matches with friends were found to have high levels of violent tendencies.
\end{abstract}

Keywords: Football, fan, hopelessness, violence tendency

\section{Introduction}

It is known that fans have an important place in football, a sport that is very popular in modern times. Fans can sometimes display psychologically negative emotions while watching football. Hopelessness and tendency to violence, which are among these negative emotional states, have important roles on football supporters.

Hopelessness is generally thought to originate in the lack of hope an individual has about life. Looking at the difference between hope and hopelessness, hope can be expressed as a situation that will exist in the future or where the individual wants to see themselves in the future and hopelessness can be expressed as the negativities they experience when their expectations for the future are not fulfilled. When the literature is examined, it is seen that there are different definitions of hope and hopelessness. According to the definition of the Turkish Language Association, hope expresses a situation that is expected, while hopelessness is expressed as despair and pessimism about an event about to occur (URL-1). According to the definition of the American Psychological Association, hopelessness 
is a subjective emotional state in which the individual thinks they have no freedom of choice or their options are limited (Abramson et al., 1989). Horney (1993) defines hopelessness as a reaction to situations that are considered a failure that is out of proportion to the actual dimensions of the event. In contrast, Panzarella et al. (2006) define hopelessness as an individual defining themselves with negative features, having negative expectations about the future, and seeing negative life events as unchanging. Despite these definitions, hopelessness can be expressed as a negative cognitive assessment in which life events are perceived negatively, although it includes a person's lack of well-being, reluctance, and aimlessness. When these situations persist, many different emotional states arise, such establishing unhealthy relationships, misrepresenting oneself, feeling misunderstood, and meeting one's own desires and needs by harming others through violence (Gençoğlu et al., 2014).

The World Health Organization (WHO) has defined violence as injury, death, or physical harm to another person or a certain community or group. The underlying causes of violence are reported as alcohol and substance abuse, chronic diseases, infectious diseases such as AIDS, and mental distress (WHO, 2020). When groups of fans and their behaviors are examined, it can be observed that many of them actually have mental problems. As a matter of fact, Özmaden (2005) stated in his study that fans regard their football areas as places where they can satisfy their violent motives, not as places where the game is to be enjoyed. When the literature is examined, it is seen that there are different definitions of violence. Ayan (2006) evaluates the meaning of violence as all kinds of material and spiritual negativity towards the physical and spiritual integrity of another person. Gençoğlu et al. (2014) define violence as different developmental disorders. Özgür et al. (2011) define violence as one of the social problems of people in developed and developing countries in the $21^{\text {st }}$ century. Zahn et al. (2004) define violence as the use of force to dominate others. From a sociological perspective, violence is defined as the transformation of anger into the behavioral dimension as a result of adverse situations such as tolerance of violence in society, violence being seen as a problem-solving method, inadequate family education, the influence of the media, gender roles, socioeconomic problems, migration, and globalization (Bilge, 2006; Baltaş, 2000; Kızmaz, 2006; Yönet et al., 2016). According to the report published by the WHO in 2014, more than 1.3 million people die every year as a result of violent situations (WHO, 2014). While violence is sometimes a tool for a specific purpose, it may also be a series of actions that occur randomly and do not have a purpose beyond satisfying the perpetrator (Göldağ, 2015). One of these action areas is football. This sport, which is currently gaining importance, developing, and spreading, has also affected large communities (Yıldırım, 2017). For fans, who are the indispensable audience of football, football is seen as an exciting part of life. However, it also has different meanings beyond being a game and a hobby (Bilir \& Sangün, 2014).

In recent years, tribunes have become a problem area, and there have been undesirable changes in the behavior of fans (Özmaden, 2005). From time to time, fans see their expectations and hopes in their private lives as places where their motivation for violence can be satisfied (Özmaden, 2005; Çağlayan \& Fişekçioğlu, 2004). When we look at history, fans who attended the horse car races held during the ancient Roman period were known to be divided into two groups: "Blues" and "Greens" (Frosdick \& Marsh, 2013). However, football, which stands in a very different place from the sporting activities of ancient times, has become a phenomenon that reflects the basic characteristics of modern society, including massification, differentiation, organization, professionalization, industrialization, commercialization, politicization, and scientization (Spaaij, 2007; Amman, 2008). In this context, the purpose of this study is to examine the relationship between the tendencies towards hopelessness and violence among football fans and to examine the differences between these variables and various demographic variables. For this purpose, answers were sought for the following questions:

1. Is there a difference between the age of the fans, the situation of going to away games, the duration of time matches are watched at the stadium, with whom matches are watched, and the variables of hopelessness and violence tendency?

2. Is there a relationship between the hopelessness of fans and the tendency towards violence?

3. Does the level of fans' hopelessness have an impact on the tendency towards violence?

\section{Method}

\section{Research model}

In this study, the general screening model, one of the quantitative research methods, was used (Karasar, 2012). 


\section{Participants}

The research group was formed by 398 male volunteer football fans who watched the Elazigspor matches in the 2018-2019 season (Sports Toto $1^{\text {st }}$ League) in Turkey.

\section{Data collection}

Violence Tendency Scale: This scale was developed for a study performed by Göka, Bayat, and Türkçapar in 1995 on behalf of the Ministry of National Education and in the study of the Prime Ministry Family Research Institution on "Violence in the Family and in the Social Space" (1998) in order to measure the violent tendencies of children 7-14 years old. The basic structure was re-patterned and the validity of the content was not changed (Republic of Turkey, Prime Ministry Family Research Institution, 1998). The scale, which is a 4-point scale (1 = Not Suitable, 4 = Very Suitable), consists of 20 items and one dimension. In the evaluations made according to the total scores, a score of 1-20 points is "very low," and a score of 21-40 points is "low;" a score of 41-60 points shows "excess," and a score of 61-80 points indicates "too much." The Cronbach alpha reliability coefficient calculated to test the reliability of the scale was found to be 0.76 . In the current study, this coefficient was found to be 0.72 .

Beck Hopelessness Scale: This scale was performed by Beck et al. (1974) and adapted to Turkish by Seber (1991). It is a 20-item self-assessment scale that aims to determine an individual's level of pessimism for the future. While the "yes" option scored 0 points in 11 items of the scale, 9 "no" option scored 1 . The cutoff scores of the scale according to the different levels of hopelessness were as follows: 0-3 was the lowest (or hopeful) level of hopelessness; 4-8 was the low level of hopelessness (mild); the level of hopelessness at 9-14 was moderate; and the level of hopelessness at 15-20 was high (intensive). The Cronbach alpha reliability coefficient calculated to test the reliability of the scale was found to be 0.86 . In the current study, this coefficient was found to be 0.77 .

\section{Data analysis}

The SPSS 24 (Statistical Package for Social Science) program was used to analyze the data obtained in the research. The Skewness and Kurtosis values were checked to determine whether the data showed a normal distribution. These values were checked and evaluated between -1 and +1 (Mertler \& Vannatta, 2005). As a result of this evaluation, it was seen that the data showed normal distribution. Accordingly, an independent samples t-test, one-way ANOVA, pearson correlation, and linear regression analysis were applied to the statistical analysis.

\section{Results}

In this section, the relationship between the variables of hopelessness and violence tendency of football fans participating in the research, effect-based analysis, and a detailed breakdown of the differences between various demographic variables are given in the tables.

Table 1. One-way ANOVA results of hopelessness and violence tendency according to the age variable of individuals

\begin{tabular}{lccccccc}
\hline Variable & Age & $\mathrm{n}$ & $\bar{x}$ & $\mathrm{SD}$ & $\mathrm{F}$ & $\mathrm{p}$ & $\begin{array}{c}\text { Source of the } \\
\text { difference }\end{array}$ \\
\hline \multirow{3}{*}{ Hopelessness } & ${ }^{\mathrm{A}} 18-21$ & 102 & 5.95 & 3.50 & & & \\
& $\mathrm{~B} 22-25$ & 96 & 6.55 & 3.66 & 2.782 & $.041^{*}$ & A-D \\
& ${ }^{\mathrm{C}} 26-29$ & 93 & 7.09 & 3.97 & & & \\
\hline \multirow{3}{*}{ Violence tendency } & D30 and above & 107 & 7.43 & 4.47 & & & \\
& ${ }^{\mathrm{A}} 18-21$ & 102 & 41.92 & 6.37 & & & \\
& ${ }^{\mathrm{B}} 22-25$ & 96 & 39.84 & 7.06 & & & \\
& ${ }^{\mathrm{C}} 26-29$ & 93 & 40.87 & 7.69 & & & \\
\hline
\end{tabular}

$* \mathrm{p}<.05$ 
When Table 1 was examined, it was determined that there was a statistically significant difference between the age variable of the groups participating in the research and the variable of hopelessness. This difference was found to be between those aged 18-21 and those aged 30 and above.

Table 2. Hopelessness and violence tendency results according to individuals going to away games t-test results

\begin{tabular}{lcccccc}
\hline Variables & $\begin{array}{c}\text { The situation of going } \\
\text { to away matches }\end{array}$ & $\mathrm{n}$ & $\bar{x}$ & $\mathrm{SD}$ & $\mathrm{t}$ & $\mathrm{p}$ \\
\hline \multirow{2}{*}{ Hopelessness } & Yes & 288 & 6.78 & 4.05 & .155 & .877 \\
& No & 110 & 6.71 & 3.70 & & \\
Violence tendency & Yes & 288 & 41.41 & 6.95 & 2.602 & $.010^{*}$ \\
\hline
\end{tabular}

$* \mathrm{p}<.05$

When Table 2 was analyzed, it was observed that there was a statistically significant difference between the variables of the participating fans going to away games and violence tendency.

Table 3. One-way ANOVA results of individuals' hopelessness and violence tendency according to the duration of watching the matches at the stadium

\begin{tabular}{|c|c|c|c|c|c|c|c|}
\hline Variables & $\begin{array}{l}\text { Duration of watching the } \\
\text { matches at the stadium }\end{array}$ & $\mathrm{n}$ & $\bar{x}$ & $\mathrm{SD}$ & $\mathrm{F}$ & $\mathrm{p}$ & $\begin{array}{l}\text { Source of } \\
\text { difference }\end{array}$ \\
\hline \multirow{4}{*}{ Hopelessness } & ${ }^{\mathrm{A}} 1-4$ years & 73 & 6.19 & 3.60 & \multirow{4}{*}{1.366} & \multirow{4}{*}{.253} & \multirow{4}{*}{-} \\
\hline & ${ }^{\mathrm{B}} 5-9$ years & 125 & 6.57 & 4.13 & & & \\
\hline & ${ }^{\mathrm{C}} 10-14$ years & 106 & 7.34 & 3.77 & & & \\
\hline & D15 years and above & 94 & 6.80 & 4.15 & & & \\
\hline \multirow{4}{*}{ Violence tendency } & $\mathrm{A} 1-4$ years & 73 & 38.88 & 5.71 & \multirow{4}{*}{3.134} & \multirow{4}{*}{$.026^{*}$} & \multirow{4}{*}{ A-D } \\
\hline & B5-9 years & 125 & 40.88 & 6.90 & & & \\
\hline & ${ }^{\mathrm{C}} 10-14$ years & 106 & 41.02 & 7.00 & & & \\
\hline & ${ }^{\mathrm{D}} 15$ years and above & 94 & 42.17 & 7.70 & & & \\
\hline
\end{tabular}

${ }^{*} \mathrm{p}<.05$

When Table 3 was examined, it was found that there was a statistically significant difference between the match watching time variable and violence tendency among the fans who participated in the research. It was determined that this difference was between those who went to watch the matches for 1-4 years at the stadium and those who watched the matches for 15 years or more at the stadium.

Table 4. One-way ANOVA results of hopelessness and violence tendency according to the variable of with whom fans go to the matches at the stadium

\begin{tabular}{|c|c|c|c|c|c|c|c|}
\hline Variable & $\begin{array}{l}\text { Match watching } \\
\text { status }\end{array}$ & $\mathrm{n}$ & $\bar{x}$ & $\mathrm{SD}$ & $\mathrm{F}$ & $\mathrm{p}$ & $\begin{array}{l}\text { Source of } \\
\text { differences }\end{array}$ \\
\hline \multirow{3}{*}{ Hopelessness } & ${ }^{\mathrm{A}}$ Alone & 183 & 7.31 & 4.02 & \multirow{3}{*}{3.834} & \multirow{3}{*}{$.022 *$} & \multirow{3}{*}{$\mathrm{A}-\mathrm{C}$} \\
\hline & ${ }^{B}$ With family & 96 & 6.60 & 4.05 & & & \\
\hline & ${ }^{\mathrm{C}}$ With friends & 119 & 6.04 & 3.68 & & & \\
\hline \multirow{3}{*}{ Violence tendency } & A Alone & 183 & 39.88 & 6.37 & \multirow{3}{*}{3.386} & \multirow{3}{*}{$.035^{*}$} & \multirow{3}{*}{$\mathrm{A}-\mathrm{C}$} \\
\hline & ${ }^{B}$ With family & 96 & 41.52 & 7.36 & & & \\
\hline & ${ }^{\mathrm{C}}$ With friends & 119 & 41.82 & 7.43 & & & \\
\hline
\end{tabular}

$* \mathrm{p}<.05$ 
When Table 4 was analyzed, a statistically significant difference was found between the variable of who participated in the research to watch the matches and violence tendency and hopelessness. It was observed that this difference was at both the level of hopelessness and violence tendency between those who went alone to watch matches and those who went with their friends.

Table 5. Pearson correlation analysis between hopelessness and violence tendency

\begin{tabular}{lccc}
\hline Variables & & Hopelessness & Violence tendency \\
\hline Hopelessness & $\mathrm{r}$ & 1 & \\
& $\mathrm{p}$ & & \\
Violence tendency & $\mathrm{r}$ & $.502^{* *}$ & 1 \\
& $\mathrm{p}$ & .000 & \\
\hline
\end{tabular}

$\mathrm{n}=398 ; * * \mathrm{p}<.01$

Table 6. The effect of hopelessness on violence tendency

Dependent variable: violence tendency

\begin{tabular}{lccccc}
\hline Variables & $\mathrm{B}$ & Standard error & $\beta$ & $\mathrm{t}$ & $\mathrm{p}$ \\
\hline (Constant) & 32.724 & .765 & & 42.749 & .000 \\
Hopelessness & .968 & .084 & .502 & 11.566 & .000 \\
\hline
\end{tabular}

$\mathrm{R}^{2}=.252 ;{ }_{\text {adj. }} \mathrm{R}^{2}=.251 ; \mathrm{F}=133.764 ; \mathrm{p}<.01$

\section{Discussion and conclusion}

As a result of the analysis conducted to determine the differences between the hopelessness and violence tendency variables and various demographic variables of football fans participating in the research, it was seen that there was a statistically significant difference in the hopelessness levels of the fans according to their ages and with whom they watched the matches. In addition, it was determined that there was a statistically significant difference in the tendency to use violence according to the variables of fans going to away matches, the duration of match watching at the stadium, and with whom fans went to watch the matches. It is thought that desperation levels increase with age because those with a greater tendency towards violence were those who went to away games and watched games at the stadium for many years. This increase in violent tendencies could have something to do with increased team loyalty over time. In the case of loyalty, since any negative situation for the team will affect the individual negatively, the individual can feel despair and have a tendency to use violence when their team loses. Branscombe and Wann (1991) investigated the relationship between team identification and positive and negative emotions, reporting that high team identification positively affects positive emotions such as happiness, joy, satisfaction, and life satisfaction, while low team identification positively affects negative emotions such as unhappiness, regret, worthlessness, resentment, and hopelessness. Yüksel et al. (1998) stated that fans sometimes satisfy their expectations and hopes in their private lives with the success of a team or club. According to Zielinski and Bajorek (2013), the specific character of different behaviors in a sport audience can allow us to divide football match viewers into two categories. One of these categories consists of regular viewers (football fans and consumers) who take part in a show and enjoy it without causing any problems. The other consists of football fans who identify themselves with their club and can function as ultras, supporters, and pseudo-fans who highlight victory in a provocative and noisy way.

When the correlation analysis results of the fans' hopelessness and violence tendency variables were examined, it was determined that there was a moderate positive relationship between fans' violence tendency and their hopelessness levels. Accordingly, it can be said that as fans' levels of despair increase, the level of violence education increases. In the regression analysis regarding the hopelessness variable and the trend of violence, it was found that 
the hopelessness variable could explain the violence trend by approximately $25 \%$. The remaining $75 \%$ is thought to be affected by the educational situation, family relations, problems in economic and social life, lack of sports culture related to passive participation, insufficient stadiums that cannot meet safety standards, ineffective security measures, club managers who cannot accommodate the interests of the fans, and the media. The psychological commitment of fans to their teams and identification with their teams can lead to violence and aggression in football (Konter, 2006), even if they are happy with the team they support. When they lose, they feel anger, sadness, hopelessness, and depression. Dekaristos (2016) stated in his work with football fans that some fans wanted to attack the police who were at the stadium when their team lost. The sadness of a team's defeat is felt deeper than the sense of victory (Forsyth, 2010). Along with hopelessness, feelings of worthlessness, helplessness, unhappiness, indecision, failure to act, and lack of motivation, feelings of guilt can also arise (Dilbaz \& Seber, 1993). The pessimistic approach and feelings of failure that emerge with hopelessness (Tümkaya, 2005) may lead to heightened levels of violence and aggression among fans. Kula (2008) reported that as hopelessness increases, aggression also increases. In addition, Pulur et al. (2004) stated that the most important source of violence in football is the contradiction of "good team-bad result." This increases the individual's symbols of self-definition and the conflict within themselves. The researchers emphasized that the pressure will increase as a result of the growth of this contradiction, and the individual will turn to various undertakings (violence, aggression, bad cheer, etc.) to resolve this contradiction. As a result, as the level of fans' despair increased, there was also an increase in the tendency to use violence. In addition, it was determined that those who went to watch away games, those who watched the matches at the stadium, and who went to matches with their friends had high tendencies towards violence.

\section{Limitations and recommendations}

This study was limited to 398 male Elazigspor fans who came to watch the matches during the 2018-2019 season. In line with the results of the study, it is recommended that the relevant supporter associations and football clubs organize and implement projects that will reduce the violence tendency of fans and contribute to their psychological positivity. In addition, the economic level of the fans participating in this study has not been examined, and economic problems are among the causes of despair and violence (Shihadeh \& Steffensmeier, 1994; Umlauf et al., 2015). Differences in regions should also be considered in such studies. Cultural differences are among the factors that determine the level of violence and hopelessness of fans and athletes. When the related literature is examined, there are studies supporting this view. For instance, as Carnibella et al. (1996) conclude, "Different historical, social, political and cultural traditions have affected the nature and scale of football related violence in different European countries."

\section{Conflicts of interest}

No potential conflict of interest was reported by the authors.

\section{Acknowledgments}

This study was presented as an oral presentation at the $2^{\text {nd }}$ International Recreation and Sports Management Congress 11-14 April 2019 in Muğla, Turkey.

\section{References}

Abramson, L. Y., Metalsky, G. I., \& Alloy, L. B. (1989). Hopelessness depression: A theory-based subtype of depression. Psychological Review, 96(2), 358-372.

Amman, M. T. (2008). Sporun Toplumsal Dinamikleri [Turkish] /Social Dynamics of Sports/. Editör: Leyla Tavacioğlu, Birgül Arslanoğlu, Spor bilimlerinde güncel yaklaşımlar. İTÜ Beden Eğitimi, İstanbul.

Ayan, S. (2006). Şiddet ve fanatizm [Turkish] /Violence and fanaticism/. CÜ İktisadi ve İdari Bilimler Dergisi, 7(2), 191209.

Baltaş, Z. (2000). Sağllk Psikolojisi [Turkish] /Health Psychology/. İstanbul: Remzi Kitabevi.

Beck, A. T., Weissman, A., Lester, D. \& Texler, L. (1974). The measurement of pessimism: the hopelessness scale. Journal of Consulting and Clinical Psychology, 42(6), 861-865.

Bilge, F. (2006). Ergenlerin öfkeyle baş etmelerine nasıl yardımcı olabiliriz? [Turkish] /How can we help adolescents cope with anger?/. Çocuk ve ergene yönelik şiddetin önlenmesi sempozyumu, 15-16 Mayıs 2006. Ankara/Turkey. 
Bilir, P., \& Sangün, L. (2014). Adana Demirspor ve Adanaspor Futbol Taraftarlarinin Şiddet Eğilimleri [Turkish] /Violence Tendencies of Adana Demirspor and Adanaspor Football Fans/. Spor ve Performans Araştırmaları Dergisi, 5(1), 56-65.

Branscombe, N. R., \& Wann, D. L.(1991). The positive social and self-concept consequences of sports team identification. Journal of Sport and Social Issues, 15(2), 115-127.

Çağlayan, H. S., \& Fişekçioğlu, İ. B. (2004). Futbol seyircisini şiddete yönelten faktörler [Turkish] /Factors driving the football audience to violencel. Selçuk Üniversitesi Sosyal Bilimler Enstitüsü Dergisi, 12, 127-142.

Dekaristos, E. M. (2016). Hooligans'attitudes regarding sport violence: a phenomenological study. University of Thessaly, Department of Physical Education and Sport Sciences (Master's thesis), Greece.

Devecioğlu, S. (2004). Sporun ekonomik boyutu [Turkish] /Economic dimension of sports/. Standart Ekonomik ve Teknik Dergi TSE, 43(511), 1-11.

Dilbaz, N., \& Seber, G. (1993). Hopelessness: Its Role in Depression and Suicide. Journal of Crisis, 1(3), $134-138$.

Forsyth, D. R. (2010). Group Dynamics. (5th ed). Wadsworth/Cengage: Belmont, CA.

Frosdick, S., \& Marsh, P. (2013). Football hooliganism. London: Routledge.

Gençoğlu, C., Kumcağiz, H., \& Ersanli, K. (2014). Family factors affecting violent tendency in adolescents. Electronic Turkish Studies, 9(2), 639-652.

Göldağ, B. (2015). The level of violence disposition of students and their value perceptions. TÜBAV Journal of Science, $8(4), 1-15$.

Karasar, N. (2012). Bilimsel Araştırma Yöntemi [Turkish] /Scientific Research Method/. Ankara: Nobel Akademik Yayıncilik.

Kizmaz, Z. (2006). A theoretical approach to the roots of violence behaviors at schools. Journal of Social Science, 30 , 47-70.

Konter, E. (2006). Spor Psikolojisi El Kitabı [Turkish] /Sports Psychology Handbook/ Ankara: Nobel Yayinevi.

Kula, E. (2008). Examination of the relation between the hopelessness level and aggression status of the students of industrial vocational high school. Yeditepe University, Institute of Social Sciences, Master Thesis, İstanbul, Turkey.

Mertler, C. A., \& Vannatta, R. A. (2005). Advanced and Multivariate Statistical Methods: Practical Application and Interpretation. Los Angeles: Pyrczak Publishing.

Miguel, E., Saiegh, S. M., \& Satyanath, S. (2008). National Cultures and Soccer Violence (No. w13968). National Bureau of Economic Research, NBER Working Paper.

Özgür, G., Yörükoğlu, G., \& Baysan-Arabac1, L. (2011). High school student's perception of violence, level of tendency to violence and effective factors. Journal of Psychiatric Nursing, 2(2), 53-60.

Özmaden, M. (2005). Opinions of football audience on aggressive behaviors: a case STUDY (Example OF Kirşehir). Kastamonu Education Journal, 13(2), 663-674.

Panzarella, C., Alloy, L. B., \& Whitehouse, W. G. (2006). Expanded hopelessness theory of depression: On the mechanisms by which social support protects against depression. Cognitive Therapy and Research, 30(3), 307-333.

Pulur, A., Kaynak, İ., \& Orhan, S. (2004). The investigation of the effect of supportive attitudes of police on their interfering behaviors towards aggressive spectators in sports competitions. Kırşehir Journal of Faculty of Education, 5(2), 241-260.

Republic of Turkey, Prime Ministry Family Research Institution (T.C. Başbakanlık Aile Araştırma Kurumu) (1998). Aile Içinde Şiddet Ve Toplumsal Alanda Şiddet [Turkish] /Violence within the Family and Violence in the Social Sphere/. Ankara: Başbakanlık Basımevi.

Seber, G. (1991). Beck umutsuzluk ölçeğinin geçerliği ve güvenirliği üzerine bir çalışma [Turkish] /A study on the validity and reliability of the Beck hopelessness scale/. Doçentlik Tezi, Anadolu Üniversitesi Tıp Fakültesi, Psikiyatri Anabilim Dalı, Eskişehir.

Shihadeh, E. S., \& Steffensmeier, D. J. (1994). Economic inequality, family disruption, and urban black violence: Cities as units of stratification and social control. Social Forces, 73(2), 729-751.

Spaaij, R. (2007). Football hooliganism in the Netherlands: Patterns of continuity and change. Soccer \& Society, 8(2-3), 316-334.

Tümkaya, S. (2005). Comparing the hopelessness of the adolescents who live with their families and who live in the orphanages. The Journal of Turkish Educational Sciences, 3(4), 445-457.

Umlauf, M. G., Bolland, A. C., Bolland, K. A., Tomek, S., \& Bolland, J. M. (2015). The effects of age, gender, hopelessness, and exposure to violence on sleep disorder symptoms and daytime sleepiness among adolescents in impoverished neighborhoods. Journal of Youth and Adolescence, 44(2), 518-542.

URL-1 http://tdk.gov.tr Date of Access: 14.04.2020 
World Health Organization (WHO), (2014). Global status report on violence prevention. Luxemburg, p. 1-2.

World Health Organization (WHO), (2020). World report on violence and health. Geneva. Luxemburg p. 1-46.

Yildırım, M. (2017). Determination of the views of football spectator's about aggressive attitudes. Journal of International Social Research, 10(50), 1046-1057.

Yönet, E., Calik, F., Yasartürk, F., \& Cimen, K. (2016). Investigation of high school student's participation in recreational activities and aggression-violence tendency. International Journal of Sport Culture and Science, 4(Special Issue 1), 368-382.

Yüksel, H., Doğan, B, Moral, S., \& Acar, M. F. (1998). Dimensions of violence in soccer. Journal of Sports and Performance Researches, 5(1), 22-26.

Zahn, M. A., Brownstein, H. H. \& Jackson, S. L. (2004). Violence: From Theory to Research. New York: Matthew Bender \& Company Inc.

This is Open Access article distributed under the terms of CC-BY-NC-ND 4.0 International License. 